\title{
Prevention of Adoptively Transferred Diabetes in Nonobese Diabetic Mice with IL-10-Transduced Islet-specific Th1 Lymphocytes \\ A Gene Therapy Model for Autoimmune Diabetes
}

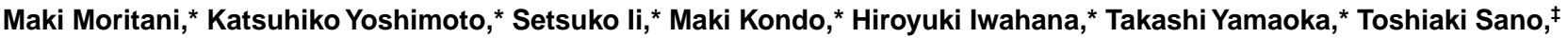 \\ Naoko Nakano, ${ }^{\S}$ Hitoshi Kikutani, ${ }^{\S}$ and Mitsuo Itakura* \\ * Otsuka Department of Clinical and Molecular Nutrition, and ${ }^{\ddagger}$ Department of Pathology, School of Medicine, \\ The University of Tokushima, Tokushima, 770 Japan; and ${ }^{\S}$ The Institute for Molecular and Cellular Biology, Osaka University, \\ Osaka, 565 Japan
}

\begin{abstract}
Four pancreatic islet-specific CD4 ${ }^{+}$helper $\mathrm{T}$ (Th) 1 (Th1) clones and two Th1 clones transduced with an SR $\alpha$ promoter-linked murine IL-10 (mIL-10) cDNA of 2.0-6.0 $\times 10^{6}$ cells were adoptively transferred to nonobese diabetic (NOD) mice at age $8 \mathrm{~d}$. Cyclophosphamide (CY) was administered at age $37 \mathrm{~d}$ (plus CY), and the incidence of diabetes and the histological grade of insulitis were examined at age $47 \mathrm{~d}$. After the adoptive transfer of IL-10-transduced Th1 cells, polymerase chain reaction (PCR) and reversetranscription (RT)-PCR detected the neo gene and the retrovirus vector-mediated IL-10 mRNA in situ in recipient islets, respectively. RT-PCR detected the decrease of IFN- $\gamma$ mRNA relative to IL-10 mRNA in IL-10-transduced Th1 clones in vitro and also in recipient islets. All four wild type Th1 clones plus CY induced the insulitis grade of 2.75 and diabetes in $66 \%$ of recipient NOD mice. IL-10-transduced two Th1 clones plus CY induced periinsulitis with the grade of 1.43 and diabetes in $8.0 \%$. The $1: 1$ mixture of wild type Th1 cells and IL-10-transduced Th1 cells plus CY induced periinsulitis with the grade of 1.85 and diabetes in $20 \%$. The suppression of diabetes through decreasing IFN- $\gamma$ mRNA by the tissue-specific delivery of IL-10 to pancreatic islets with IL-10-transduced Th1 cells affords us the starting basis to develop the gene therapy for autoimmune diabetes. ( $J$. Clin. Invest. 1996. 98:1851-1859.) Key words: insulindependent diabetes mellitus $\bullet$ insulitis - Th2 2 pancreatic islet B cells (islet B-cells) • somatic gene therapy
\end{abstract}

\section{Introduction}

Nonobese diabetic (NOD) ${ }^{1}$ mice are an animal model of insulin-dependent diabetes mellitus resulting from autoimmune

Address correspondence to Mitsuo Itakura, M.D., Ph.D., Otsuka Department of Clinical and Molecular Nutrition, School of Medicine, The University of Tokushima, Kuramoto, Tokushima-city, Tokushima, 770 Japan. Phone: 81-886-31-7097; FAX: 81-886-31-9476; E-mail: itakura@nutr.med.tokushima-u.ac.jp

Received for publication 16 April 1996 and accepted in revised form 30 July 1996.

1. Abbreviations used in this paper: CY, cyclophosphamide; NOD, non-obese diabetic mice.

J. Clin. Invest.

(C) The American Society for Clinical Investigation, Inc. 0021-9738/96/10/1851/09 \$2.00

Volume 98, Number 8, October 1996, 1851-1859 destruction of pancreatic islet B-cells (islet B-cells). Diabetes in NOD mice is preceded by insulitis consisting mostly of T cells (1). Direct evidence for both autoimmunity and $\mathrm{T}$ cell involvement in insulitis and diabetes in NOD mice has been provided by $\mathrm{T}$ cell ablation and adoptive transfer experiments. Diabetes can be transferred to NOD mice by splenocytes (2), bone marrow cells $(3,4)$, or purified T cell subpopulation $(5,6)$ of diabetic NOD mice. Although both $\mathrm{CD} 4^{+}$and $\mathrm{CD}^{+} \mathrm{T}$ cell subsets were shown to be involved $(5,6)$, islet-specific $\mathrm{CD}^{+}$ Th clones $(7,8)$ or $\mathrm{CD}^{+}$clones $(9)$ alone could transfer diabetes to NOD mice.

The immunological signals of self-reacting Th cells are regulated in part by IFN- $\gamma$, IL-10, and other cytokines. IL-1, TNF- $\alpha$, $-\beta$, and IFN- $\gamma$ were shown to directly destroy islet B-cells, and inhibit insulin secretion in vitro (10-12). Transgenic expression of IFN- $\gamma$ or $-\alpha$ in islet B-cells induced autoimmune insulitis and diabetes in non-NOD mice $(13,14)$. On the other hand, systemic administration of IL-2, $-4,-10$, or even cytotoxic cytokines of IL- 1 , TNF- $\alpha$, and $-\beta$ protected NOD mice and other animal models of insulin-dependent diabetes mellitus from becoming diabetic (15-20). The systemic administration of antiIFN- $\gamma,-\alpha$, or IL- 6 monoclonal antibody protected the onset of diabetes in NOD mice $(21,22)$.

Two types of Th cells, Th1 and Th2, with distinct cytokine secretion patterns, have been described both in mice $(23,24)$ and humans $(25,26)$. IL-10 derived mainly from Th2 inhibits macrophage-dependent antigen (Ag) presentation, Ag-specific $\mathrm{T}$ cell proliferation, and production of IFN- $\gamma$ by Th1 in vitro (27). These findings suggest that IL-10 inhibits autoimmune diabetes in vivo. On the other hand, transgenic expression of IL-10 in islet A- or B-cells in NOD mice aggravated insulitis and accelerated the onset of diabetes $(28,29)$.

To deliver IL-10 to pancreatic islets in vivo and to test its local effects on the immunological destruction of islet B-cells in NOD mice, we tried to use islet-specific Th1 clones (30) as a vehicle to deliver IL-10 to pancreatic islets. After the adoptive transfer of wild type Th1 clones, IL-10-transduced Th1 cells, or the mixture of the two to neonatal NOD mice, IL-10 and IFN- $\gamma$ mRNA levels in recipient islets, the incidence of diabetes, and the histological grades of insulitis were examined.

\section{Methods}

Th1 clones and maintenance. Four islet-specific Th1 clones named 7-10-D.3, 4-1-G.4, 4-1-K.1, and 4-1-L.6 (abbreviated as D, G, K, and $\mathrm{L}$ ), in which the IFN- $\gamma$ mRNA was detected by the RT-PCR analysis (Fig. 1), were established from infiltrating T cells within islets of 7-11 wk-old NOD mice (30). These four Th1 clones having different $\mathrm{T}$ cell receptor (TCR) repertoires (30) were maintained in RPMI-1640 with $10^{-5} \mathrm{M} \beta$-mercaptoethanol and 10\% fetal bovine serum (Hyclone, 

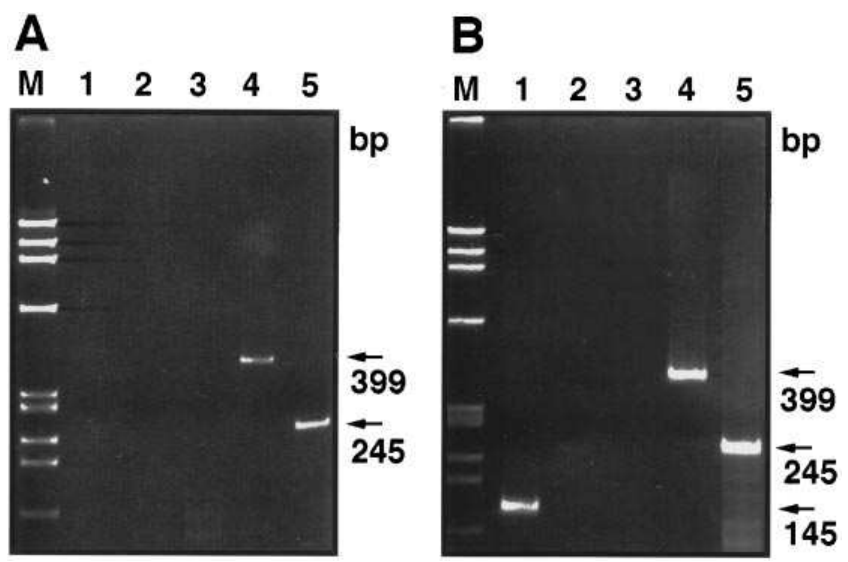

Figure 1. RT-PCR detection of cytokine mRNAs in wild type Th1 clones and IL-10-transduced Th1 cells. Ethidium bromide-stained polyacrylamide gels showing RT-PCR-amplified fragments with each pair of primers for IL-10, $-2,-4$, IFN- $\gamma$, and $\beta$-actin mRNA are presented. $(A)$ Total RNA in $1 \mu \mathrm{g}$ isolated from Th1 clones was reversetranscribed using random primers. Lane $M$ in all figures shows a DNA size marker of Hae III-digested $\phi X 174$. Lanes $1-5$ show RTPCR-amplified fragments of total IL-10 (145 bp), IL-2 (230 bp), IL-4 (399 bp), IFN- $\gamma$ (399 bp), and $\beta$-actin (245 bp) mRNA, respectively. The arrows indicate the RT-PCR-amplified fragments of IFN- $\gamma$ and $\beta$-actin mRNA. (B) Total RNA in $1 \mu \mathrm{g}$ isolated from IL-10-transduced Th1 cells was reverse-transcribed using random primers. Lanes 1-5 are the same as in $A$. The arrows indicate the RT-PCR-amplified fragments of IFN- $\gamma, \beta$-actin, and total IL-10 mRNA.

Logan, UT). Growth of the Th1 clones was stimulated by culturing 1 $\times 10^{6}$ cells of each clone with $1 \times 10^{5}$ irradiated dispersed NOD islet cells as Ag, $1 \times 10^{7}$ irradiated NOD splenocytes as Ag-presenting cells (APCs), and $20 \mathrm{U} / \mathrm{ml}$ of recombinant mIL-2 (Becton Dickinson, Bedford, MA) in a $25 \mathrm{~cm}^{2}$ culture flask with $5 \mathrm{ml}$ of culture medium. To obtain $2 \times 10^{6}$ islet cells, the pancreata of eight NOD mice were perfused with collagenase ( $1 \mathrm{mg} / \mathrm{ml}$; Nitta Gelatin, Osaka, Japan) dissolved in HBSS followed by the incubation at $37^{\circ} \mathrm{C}$ for $30 \mathrm{~min}$ (30). Islets were washed three times with HBSS, and placed in a discontinuous density gradient of Ficoll (model Ficoll-400; Pharmacia Fine Chemicals, Uppsala, Sweden) at 25, 23, 21, and 15\%. After centrifugation at $850 \mathrm{~g}$, islets were removed from $15-21 \%$ and $21-23 \%$ interface, washed with RPMI-1640, and dispersed into single cells in $0.02 \%$ EDTA solution (Nakalai Tesque, Kyoto, Japan). The cells were irradiated with 3,000 rad from a ${ }^{60} \mathrm{Co}$ source and resuspended in culture medium. Splenocytes from 2 NOD mice were filtered through a cell sieve of a $200 \mu \mathrm{m}$ mesh size, resuspended in RPMI-1640, and centrifuged at $400 \mathrm{~g}$. After washing, splenocytes were similarly irradiated, resuspended in RPMI-1640, and used as APCs. Th1 clones were restimulated every $10 \mathrm{~d}$ with $\mathrm{Ag}$ and APC.

$R T-P C R$ detection of IL-10, -2, -4, and IFN- $\gamma m R N A .200 \mathrm{mg} / \mathrm{kg}$ body weight (BW) of CY (Shionogi, Osaka, Japan) was administered i.p. at age $37 \mathrm{~d}$ (plus CY) in the adoptive transfer experiment. Total RNA was isolated from wild type Th1 clones, IL-10-transduced Th1 cells, and recipient islets after the adoptive transfer of wild type Th1 clones plus CY or IL-10-transduced Th1 cells plus CY with the guanidium isothiocyanate-phenol-chloroform procedure. Total RNA in $1 \mu \mathrm{g}$ treated with RNase-free DNase (Promega Corp., Madison, WI) was reverse-transcribed with $100 \mathrm{U}$ of Moloney Murine Leukemia Virus (Mo-MLV) reverse transcriptase (RTase) (Promega Corp.) and $100 \mathrm{pM}$ of random hexamer primers (Pharmacia Fine Chemicals) in $20 \mu \mathrm{l}$ of RT-reaction buffer containing $0.5 \mathrm{mM}$ each of dNTPs, $1 \mathrm{mM}$ dithiothreitol, and $20 \mathrm{U}$ of RNasin (Promega Corp.). After incubation at $37^{\circ} \mathrm{C}$ for $1 \mathrm{~h}$, the reaction mixture was heated at $95^{\circ} \mathrm{C}$ for $5 \mathrm{~min}$, and cDNA was stored at $-20^{\circ} \mathrm{C}$ until use. The mRNAs
A

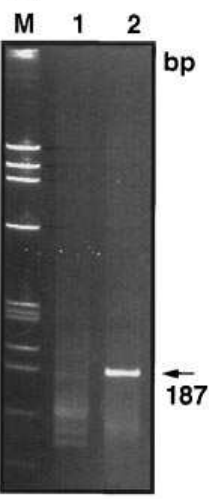

B
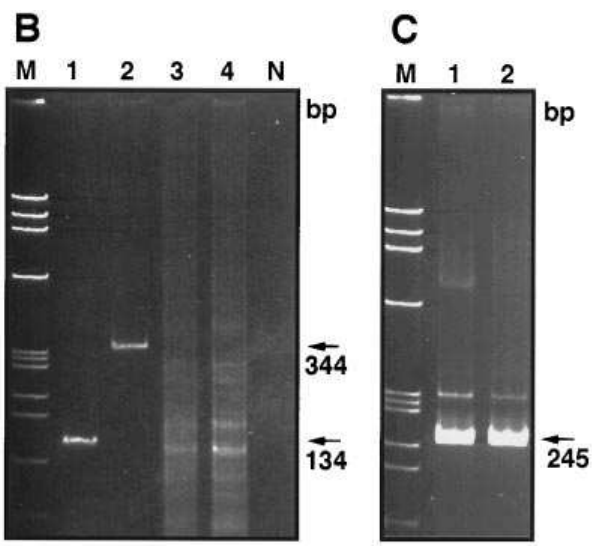

Figure 2. RT-PCR detection of IL-10 mRNA. Ethidium bromidestained polyacrylamide gels showing RT-PCR-amplified fragments of IL-10 and $\beta$-actin mRNA are presented. Total RNA in $1 \mu \mathrm{g}$ isolated from IL-10-transduced Th1 cells and recipient islets after the adoptive transfer of wild type Th1 clones plus CY or IL-10-transduced Th1 cells plus CY was reverse-transcribed using random primers. (A) Lane 1, a 187 bp RT-PCR-amplified fragment of total IL-10 mRNA from IL-10-transduced Th1 cells without RTase; lane 2, the same as lane 1 but with RTase. The arrow indicates the RT-PCRamplified fragment of total IL-10 mRNA. (B) Lanes 1 and 2, 134 and 344 bp RT-PCR-amplified fragments of retrovirus vector-mediated IL-10 mRNA as indicated with arrows, respectively, from recipient islets after the adoptive transfer of IL-10-transduced Th1 cells plus $\mathrm{CY}$; lanes 3 and 4 , the same as lanes 1 and 2 but from recipient islets after the adoptive transfer of wild type Th1 clones plus CY; lane $N$, template free. $(C)$ Lanes 1 and 2, 245 bp RT-PCR-amplified fragment of $\beta$-actin, as indicated with an arrow, from recipient islets after the adoptive transfer of IL-10-transduced Th1 cells plus CY, and wild type Th1 clones plus CY, respectively.

for IL-10, $-2,-4$, and IFN- $\gamma$ were first PCR-amplified from $1 \mu \mathrm{l}$ of synthesized cDNA in a total volume of $20 \mu \mathrm{l}$ to a plateau level at $42 \mathrm{cy}-$ cles (Figs. 1 and 2). The IL-10 and IFN- $\gamma$ mRNAs were then amplified every five cycles from 25 to 40 cycles for the semiquantitative RT-PCR cycle number analysis (Fig. 3). Each PCR cycle included denaturation at $94^{\circ} \mathrm{C}$ for $1 \mathrm{~min}$, annealing at $56^{\circ} \mathrm{C}$ for $1 \mathrm{~min}$, and extension at $72^{\circ} \mathrm{C}$ for $2 \mathrm{~min}$, with the final extension for $8 \mathrm{~min}$. PCR products were electrophoresed on an $8 \%$ polyacrylamide gel. Pairs of primers used to amplify cytokine mRNAs and $\beta$-actin mRNA as an internal control were listed in Table I. Those for IL-10 included two pairs of "A" to detect the retrovirus vector-mediated IL-10 mRNA and two pairs of "B" to detect total IL-10 mRNA including both the retrovirus vector-mediated and endogenous IL-10 mRNAs. All primer pairs were designed in separate exons to cross an intron. The RT-PCR analyses of two different mRNA preparations each for cultured wild type Th1 clones plus CY or IL-10-transduced Th1 cells plus $\mathrm{CY}$, and three different recipient islet preparations each after the adoptive transfer of wild type Th1 clones plus CY or IL-10-transduced Th1 cells plus CY were all repeated at least three times, respectively.

Construction of a retroviral vector. A $5.2 \mathrm{kbp}$ retroviral vector construct of pBabe Neo (31) containing the Mo-MLV long terminal repeats (LTRs) and the neomycin phosphotransferase gene was used to transduce wild type Th1 clones with mIL-10 cDNA. An SR $\alpha$ promoter sequence (32) of 640 bp was cut out with Hind III and Xho I from an F115 plasmid provided by K.W. Moore (DNAX Research Institute of Molecular Biology, Palo Alto, CA). This $\mathrm{SR} \alpha$ promoter sequence was inserted into a SnaB I site of a pBabe Neo vector after blunt-ending with T4 DNA polymerase (pRB501). A 600 bp Sac I 


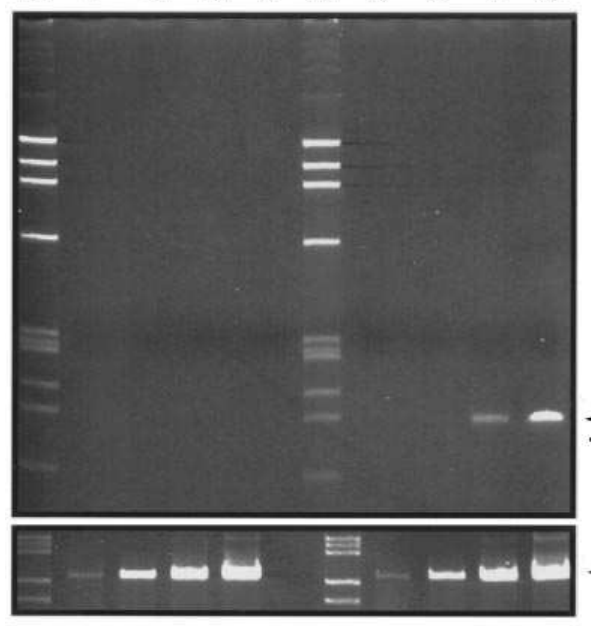

bp

187
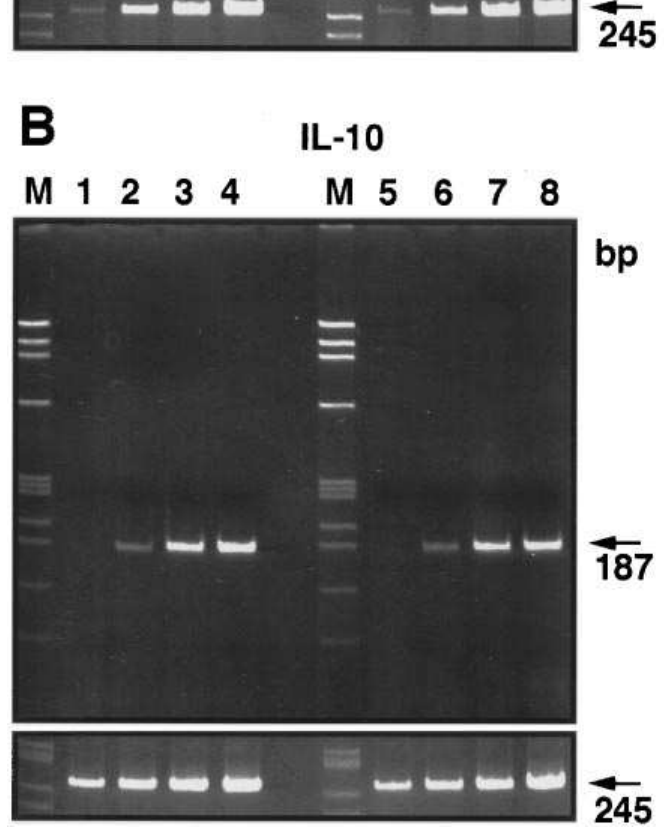
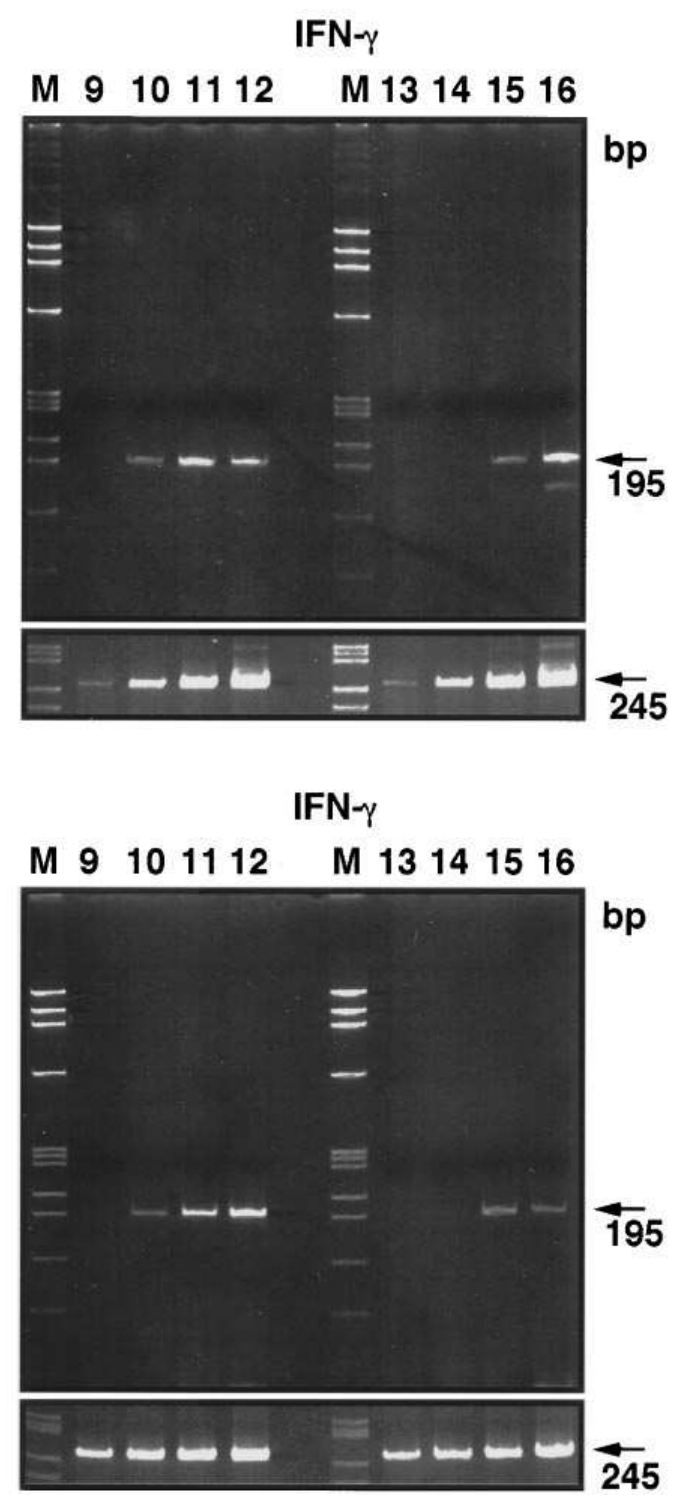

Figure 3. Semiquantitative RT-PCR cycle number analysis of IL-10 and IFN- $\gamma$ mRNAs. Total RNA in $1 \mu \mathrm{g}$ was reverse-transcribed using random primers. The ethidium bromide-stained polyacrylamide gels are presented. Lanes 1-4 or lanes 5-8 correspond to RT-PCR cycle numbers of $25,30,35$, and 40 , respectively. $(A)$ RNA was isolated from wild type Th1 clones or IL-10transduced Th1 cells. Lanes 1-4 and lanes 5-8 show the RT-PCR-amplified 187 bp fragment of total IL-10 mRNA in wild type and IL10-transduced Th1 cells, respectively, as indicated with an arrow. Lanes 9-12 and lanes 13-16 show the RTPCR-amplified 195 bp fragment of IFN- $\gamma$ mRNA in wild type and IL-10-transduced Th1 cells, respectively, as indicated with an arrow. (B) RNA was isolated from recipient islets after the adoptive transfer of wild type Th1 clones plus CY or IL-10-transduced Th1 cells plus CY. Lanes 1-16 are the same as in $A$, except that recipient islets were used instead of cultured Th1 cells. The bottom figures show the RT-PCRamplified $245 \mathrm{bp}$ fragment of $\beta$-actin mRNA, as indicated with an arrow, from the same samples in the same conditions shown in the figure above.
mIL-10 fragment was also cut out from an F115 plasmid, and subcloned into an Eco RV site of pBluescript vector (pRB402). An Eco $\mathrm{RI}$ and Sal I fragment from a pRB402 was then subcloned into an Eco $\mathrm{RI}$ and Sal I site of pRB501. The resulting retroviral vector (pRB107) contained a stretch of LTR/SR $\alpha / \mathrm{mIL}-10 \mathrm{cDNA} /$ and the neo gene (Fig. 4).

Generation of $G 418^{r}$ packaging cells and $G 418^{r}$ Th1 clones. All packaging cells were grown in DMEM with $10 \%$ FBS. An ecotropic packaging cell line of $\psi \mathrm{CRE}$ (33), was transfected with $10 \mu \mathrm{g}$ of pRB107 using the lipofectin reagent (GIBCO BRL, Gaithersburg, MD) according to the manufacturer's instruction. An amphotropic packaging cell line of $\psi$ CRIP (33) was subsequently infected with viral particles in the culture supernatant of $\psi \mathrm{CRE}$ cells, in the presence of $8 \mu \mathrm{g} / \mathrm{ml}$ of polybrene (hexadimethrine bromide; Sigma Chemical Co., St. Louis, MO) at $37^{\circ} \mathrm{C}$ for $1.5 \mathrm{~h}$. After the exposure, cells were washed with DMEM and cultured for $24 \mathrm{~h}$. After splitting these cells at the ratio of 1:20, cells were cultured for $14 \mathrm{~d}$ in the selection medium containing G418 (GIBCO BRL) at $1 \mathrm{mg} / \mathrm{ml}$ by the active weight. Virus titers in colony forming units $(\mathrm{CFU}) / \mathrm{ml}$ of $\mathrm{G} 418^{\mathrm{r}}$ $\psi$ CRIP clones were determined using NIH/3T3 cells, and mIL-10 concentrations were screened with the enzyme-linked immunosor- bent assay (34). One clone of G418 ${ }^{\mathrm{r}}-\psi \mathrm{CRIP}-8$ produced the highest titer of $8 \times 10^{6} \mathrm{CFU} / \mathrm{ml}$. This clone which produced $10 \mathrm{U} / \mathrm{ml}$ of $\mathrm{mIL}$ 10 , with the others producing $5-10 \mathrm{U} / \mathrm{ml}$ in the culture medium, was used to infect Th1 clones.

Th1 clones were exposed to 2-4 $\mathrm{ml}$ of the culture supernatant of G418 $-\psi$ CRIP -8 clone in the presence of $6 \mu \mathrm{g} / \mathrm{ml}$ of polybrene at $37^{\circ} \mathrm{C}$ for $1.5 \mathrm{~h}$, on the third day after Ag stimulation. After the exposure, these cells were washed with RPMI-1640. Cells were cultured for $14 \mathrm{~d}$ in the selection medium with G418 added at $0.3 \mathrm{mg} / \mathrm{ml}$ first on the third day after transduction. IL-10-transduced Th1 cells were cultured further for $14 \mathrm{~d}$, while the concentration of G418 was gradually increased to $0.45 \mathrm{mg} / \mathrm{ml}$ to select stable transformants. IL-10-transduced Th1 cells produced $10 \mathrm{U} / \mathrm{ml}$ of mIL-10 on the third day after Ag stimulation. G418 - IL-10-transduced D8 or G8 Th1 cells without further cloning into separate clones were used for adoptive transfer experiments of the 1:1 mixture with corresponding wild type Th1 clones.

Adoptive transfer. 2.0-6.0 $\times 10^{6}$ Th1 cells of following types, each in $200 \mu \mathrm{l}$ of PBS were transferred i.p. to NOD mice at age $8 \mathrm{~d}$. When the 1:1 mixture of wild type Th1 clones and IL-10-transduced Th1 cells were adoptively transferred, the cell number of wild and IL- 
Table I. Sequences of PCR Primer Pairs Used to Amplify mRNAs of Cytokines and $\beta$-actin

\begin{tabular}{|c|c|c|}
\hline $\begin{array}{l}\text { Forward primer } \\
\text { Reverse primer }\end{array}$ & $\begin{array}{l}\text { Sequence } \\
\text { Sequence }\end{array}$ & $\begin{array}{c}\text { Target } \\
\text { (Fragment size) (bp) }\end{array}$ \\
\hline oRB1715S & 5'-GCCTGACCCTGCTTGCTCAA-3' & IL-10 (A)* (344) \\
\hline oRB663A & 5'-CATTTCCGATAAGGCTTGG-3' & \\
\hline oRB1715S & (as above) & IL-10 (A)* (134) \\
\hline oRB515A & 5'-TCCTCATGCCAGTCAGTAAG-3' & \\
\hline oRB632S & 5'-CGGGAAGACAATAACTGCA-3' & IL-10 $(\mathrm{B})^{\ddagger}(187)$ \\
\hline oRB633A & (as above) & \\
\hline oRB1115S & 5'-ATGCGGCTGAGGCGCTGTCA-3' & IL-10 $(\mathrm{B})^{\ddagger}(145)$ \\
\hline oRB777A & 5'-CTATGCAGTTGATGAAGATG-3' & \\
\hline oRB1387S & 5'-GCAGGATGGAGAATTACAGG-3' & IL-2 (230) \\
\hline oRB1388A & 5'-GTTGTCAGAGCCCTTTAGTTT-3' & \\
\hline oRB1269S & 5'-ATGGGTCTCAACCCCCAGCTA-3' & IL-4 (399) \\
\hline oRB1270A & 5'-GCTCTTTAGGCTTTCCAGGAAGTC-3' & \\
\hline oRB1271S & 5'-CACAGTCATTGAAAGCCTAG-3' & IFN- $\gamma(399)$ \\
\hline oRB1135A & 5'-GAATCAGCAGCGACTCCTTT-3' & \\
\hline oRB1271S & (as above) & IFN- $\gamma(195)$ \\
\hline oRB1134A & 5'-TTGCTGATGGCCTGATTGTC-3' & \\
\hline oRB1634S & 5'-GTGGGCCGCTCTAGGCACCA-3' & $\beta$-actin (245) \\
\hline oRB1635A & 5'-CGGTTGGCCTTAGGGTTCAGG-3' & \\
\hline
\end{tabular}

All primers were designed in exons separated by an intron. *IL-10 (A) and *IL-10 (B) correspond to primer pairs to amplify a retroviral vector-mediated IL-10 mRNA and total IL-10 mRNA including both retroviral vector-mediated and endogenous IL-10 mRNAs, respectively.

10-transduced Th1 cells were always between $2.0-3.0 \times 10^{6}$, respectively, to make the total number between $4.0-6.0 \times 10^{6}$ cells. Four different wild type Th1 clones of D, G, K, or L (9, 9, 8, or 9), IL-10transduced Th1 cells (six for D8, and six for G8), or the 1:1 mixture of the wild type Th1 clones and IL-10-transduced Th1 cells (five for wild type D + D8, and five for wild type G + G8) were adoptively transferred to the number of mice shown in the parentheses. At age $37 \mathrm{~d}, 200 \mathrm{mg} / \mathrm{kg}$ BW of CY were administered i.p. At age 35 and $47 \mathrm{~d}$, blood was drawn from incised tails between 9:00 and 11:00 a.m. and non fasting blood glucose (BG) concentrations were assayed using a glucose analyzer (model DRI-CHEM 100; Fuji Photo Film Co., Kanagawa, Japan). Mice were considered diabetic when the nonfasting BG concentration was above $250 \mathrm{mg} / \mathrm{dl}$. At age $47 \mathrm{~d}$, islet specimens were sampled for histological analysis.

PCR detection of the neo gene. Genomic DNA was isolated from wild type Th1 clones, IL-10-transduced Th1 cells, and paraffin-embedded islet specimens. Pancreatic islets were first localized by microscopic observation of hematoxylin and eosin-stained samples. Localized islets in sections of $10 \mu \mathrm{m}$ thickness were scraped from a slide glass with a razor blade, placed in an Eppendorf tube, deparaffinized by washing twice in xylene, twice in $95 \%$ ethanol, and dried under reduced pressure. The sample was digested overnight with proteinase $\mathrm{K}$ $(200 \mathrm{mg} / \mathrm{ml})$ in $200 \mu \mathrm{l}$ of digestion buffer including $1 \times$ saline-sodium citrate, $10 \mathrm{mM}$ Tris- $\mathrm{HCl}, \mathrm{pH} 7.4,1 \mathrm{mM}$ EDTA, and $1 \%$ SDS at $37^{\circ} \mathrm{C}$. After digestion and phenol-chloroform extraction, DNA samples

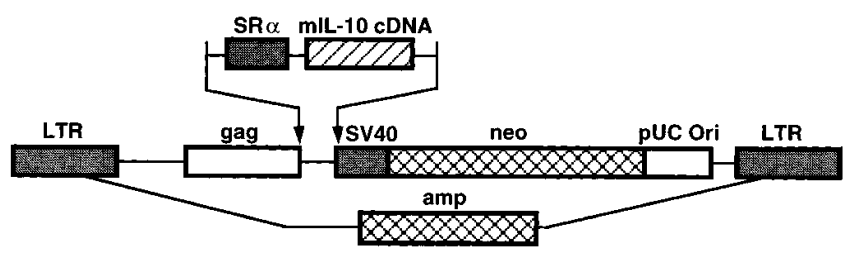

Figure 4. Schematic presentation of a retroviral vector construct. A $5.2 \mathrm{kbp}$ retroviral vector of pBabe Neo contains a stretch of Mo-MLV 5 ' and 3'-LTRs, an SR $\alpha$ promoter (640 bp), mIL-10 cDNA (600 bp), and the neomycin phosphotransferase gene (1165 bp). were introduced to PCRs. The neo gene fragment was PCR-amplified after 35 cycles of denaturation at $94^{\circ} \mathrm{C}$ for $1 \mathrm{~min}$, annealing at $59^{\circ} \mathrm{C}$ for $1 \mathrm{~min}$, and extension at $72^{\circ} \mathrm{C}$ for $2 \mathrm{~min}$ with the final extension for 10 min. Two sense and one antisense primers of oRB1264S (5'-CAAGATGGATTACACGCAGG-3'), oRB1266S (5'-GGCGATGCCTGCTTGCCGAA-3'), and oRB1265A (5'-CCCGCTCAGAAGAACTCGTC-3') were designed to yield a 791 or 236 bp PCR-amplified fragment of the neo gene.

Histological analysis. Recipient mice and age- and sex-matched control mice, six mice in each group, were killed at age $47 \mathrm{~d}$, i.e., $39 \mathrm{~d}$ after the adoptive transfer. The pancreas was excised and fixed in $3.7 \%$ formaldehyde, and processed for paraffin sectioning. Two- to three-step sections of $3 \mu \mathrm{m}$ separated by at least $30 \mu \mathrm{m}$ were stained with hematoxylin and eosin, and more than 20 islets per mouse were analyzed by an uninformed pathologist. The histological grades of insulitis were evaluated for individual islets using the following criteria of 0 to 3: 0 , intact islet without any infiltration; 1 , infiltration surrounding or involving less than $25 \%$ of the islet area; 2 , infiltration involving between 25 and $50 \%$ of the islet area; and 3, infiltration involving more than $50 \%$ of the islet area.

Statistical analysis. The percentage distribution of islets among four histological insulitis grades of 0 to 3 and the mean histological grade of insulitis in specimens of each mouse were first calculated. The mean percentage distribution of islets among four insulitis grades and the mean histological grade $\pm \mathrm{SD}$ of insulitis in each group were then calculated. Student's unpaired $t$ test was used for the statistical analysis. $P<0.05$ was considered significant.

\section{Results}

RT-PCR detection of cytokine $m R N A$. The IFN- $\gamma$ mRNA, but not mRNA of IL-2, -4 , or -10 was detected with the RTPCR analysis of the wild type Th clones (Fig. $1 A$ ). Four Th clones were thus shown to belong to the Th1 subtype. After transfecting $\psi$ CRIP packaging cells with the retroviral construct with lipofectin, 34 G418 ${ }^{\mathrm{r}}-\psi \mathrm{CR}$ IP packaging clones were selected and titered. The titers of these clones were from $1 \times$ 
$10^{3}$ to $8 \times 10^{6} \mathrm{CFU} / \mathrm{ml}$. After transduction of wild type Th1 clones with the supernatant of $\psi$ CRIP-8, the proliferation of IL-10-transduced Th1 cells did not change in comparison with wild type Th1 clones after stimulation with Ag (data not shown).

From IL-10-transduced Th1 cells of G8, a 145 (Fig. $1 B$ ) or 187 (Fig. $2 A$ ) bp PCR-amplified fragment of total IL-10 mRNA was detected, while a 399 bp PCR-amplified fragment of IFN- $\gamma$ mRNA was retained (Fig. $1 B$ ). No IL-10 mRNA signals were detected from wild type Th1 clones (Fig. $1 A$ ) or after omitting RTase from the reaction mixture in IL-10-transduced Th1 cells (Fig. $2 A$ ). The retrovirus vector-mediated IL-10 mRNA was detected as a 134 or 344 bp PCR-amplified fragment from recipient islets after the adoptive transfer of IL10-transduced Th1 cells plus CY, while no signals were detected from islets after the adoptive transfer of wild type Th1 clones plus CY (Fig. $2 \mathrm{~B}$ ).

PCR detection of the neo gene. A 791 or 236 bp PCRamplified fragment of the neo gene was detected in IL-10transduced Th1 cells of G8 (Fig. 5 A). The 236 bp PCR-amplified neo gene fragment was not detected from wild type Th1 clones of D or G, although the PCR-amplified 375 bp $\beta$-actin gene fragment was detected in all types of cells (Fig. $5 \mathrm{~B}$ ). In pancreatic specimens from two NOD mice of No. 1 and 2 after the adoptive transfer of IL-10-transduced Th1 cells of G8 plus $\mathrm{CY}$, the $236 \mathrm{bp}$ PCR-amplified fragment of the neo gene was detected (Fig. 5 B). In contrast, the neo gene fragment was not detected in pancreatic specimens of NOD mice after the adoptive transfer of wild type Th1 clones plus CY (data not shown).

RT-PCR cycle number analysis of IL-10 and IFN- $\gamma$ mRNAs. To semi-quantitate the levels of IL-10 and IFN- $\gamma$ mRNAs in

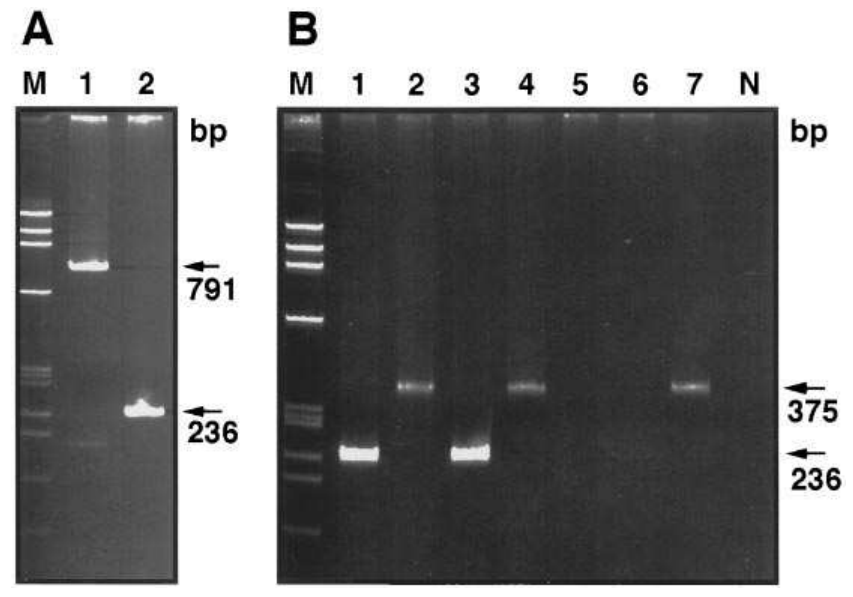

Figure 5. PCR-detection of the Neo gene. DNA was extracted from wild type Th1 clones, IL-10-transduced Th1 cells, and two recipient islet preparations from mouse No. 1 or 2 after the adoptive transfer of IL-10-transduced Th1 cells plus CY. The neo gene fragment was PCR-amplified and the ethidium bromide-stained polyacrylamide gels are presented. $(A)$ Genomic DNA from IL-10-transduced Th1 cells was used as a template. Lanes 1 and 2, amplification of the 791 and 236 bp neo gene fragments, respectively, as indicated with arrows. (B) Lanes 1 and 2, islet DNA from mouse No. 1; lanes 3 and 4, islet DNA from mouse No. 2; lanes 5-7, DNA from wild type Th1 clones; and lane $N$, template free. Lanes 1 and 3 show the PCR-amplified 236 bp neo gene fragment as indicated with an arrow; lanes 2, 4, and 7 show the PCR-amplification of the 375 bp $\beta$-actin gene fragment as a control, as indicated with an arrow. wild type Th1 clones or IL-10-transduced Th1 cells in vitro, cDNA produced from RNA was PCR-amplified at 25, 30, 35, or 40 cycles (Fig. 3 ). The PCR cycle number greater than 30 was necessary to detect the $187 \mathrm{bp}$ PCR-amplified fragment of total IL-10 mRNA from IL-10-transduced Th1 cells (Fig. 3 A, lanes 7 and 8), but it was not detected at any cycles from wild type Th1 clones (Fig. 3 A, lanes 1-4). The 195 bp PCR-amplified fragment of IFN- $\gamma$ mRNA was observed from IL-10 transduced Th1 cells after 35 cycles of PCR amplification (Fig. $3 A$, lanes 15 and 16), while it was observed after 30 cycles of PCR-amplification in wild type Th1 clones in the simultaneous assessment (Fig. $3 A$, lanes 10-12), which was confirmed by repeating at least three times for two different mRNA preparations.

Retrovirus vector-mediated IL-10 mRNA was specifically detected from recipient islets after the adoptive transfer of IL10-transduced Th1 cells plus CY (Fig. 2 B). In the semi-quantitative RT-PCR cycle number analysis of recipient islets, the 187 bp PCR-amplified fragment of total IL-10 mRNA was detected after 30 cycles of amplification at the comparable intensity after the adoptive transfer of wild type Th1 clones plus CY (Fig. 3 B, lanes 2-4) or IL-10-transduced Th1 cells plus CY (Fig $3 B$, lanes 6-8). On the other hand, IFN- $\gamma$ mRNA was detected after 35 cycles in recipient islets after the adoptive transfer of IL-10-transduced Th1 cells plus CY (Fig. 3 B, lanes 15 and 16), while it was clearly detected at 30 cycles in recipient islets after the adoptive transfer of wild type Th1 clones plus CY (Fig. 3 B, lanes 10-12), which was confirmed by repeating at least three times for three different recipient islet preparations. Thus, the level of IFN- $\gamma$ mRNA and its relative level to IL-10 mRNA were decreased in recipient islets after the adoptive transfer of IL-10-transduced Th1 cells. $\beta$-actin mRNA as a control was consistently detected and the amplified bands showed the cycle number-dependent increase in their intensities. The intensities of the $\beta$-actin bands were, however, comparable in all tested conditions.

Incidence of diabetes after adoptive transfer. The adoptive transfer of four different Th1 clones plus CY, respectively, transferred diabetes to non-diabetic NOD mice (Fig. 6). The incidence of diabetes (the number of diabetic mice/the total number of examined mice) at age $47 \mathrm{~d}$ for each of four clones of D, G, K, or L, was comparable in 78 (7/9), 67 (6/9), 63 (5/8), or $56 \%(5 / 9)$, respectively, and the mean incidence of diabetes was $66 \%(23 / 35)$ in total. Th1 clones by themselves without CY administration (minus CY) induced diabetes in 5\% (2/39). CY administration alone did not induce diabetes (0/22). There was no incidence of diabetes in control NOD mice with the administration of PBS alone (0/25).

The adoptive transfer of IL-10-transduced Th1 cells plus CY remarkably decreased the cumulative incidence of diabetes from $66 \%$ observed after the adoptive transfer of wild type Th1 clones plus CY down to 8\% (1/12) (Fig. 6). The incidence after the adoptive transfer of the 1:1 mixture of wild type Th1 clones and corresponding IL-10-transduced Th1 cells of wild type D + D8 plus CY, or wild type $\mathrm{G}+\mathrm{G} 8$ plus $\mathrm{CY}$ was $0(0 / 5)$ or $40 \%(2 / 5)$, respectively, making an incidence of $20 \%(2 / 10)$ in total (Fig. 6).

Histological analysis of pancreatic islets. To quantitatively assess the histological grade of insulitis, pancreatic islets of six NOD mice, each a control mouse, CY administration alone, after the adoptive transfer of wild type Th1 clones plus or minus CY, IL-10-transduced Th1 cells plus CY, and the 1:1 


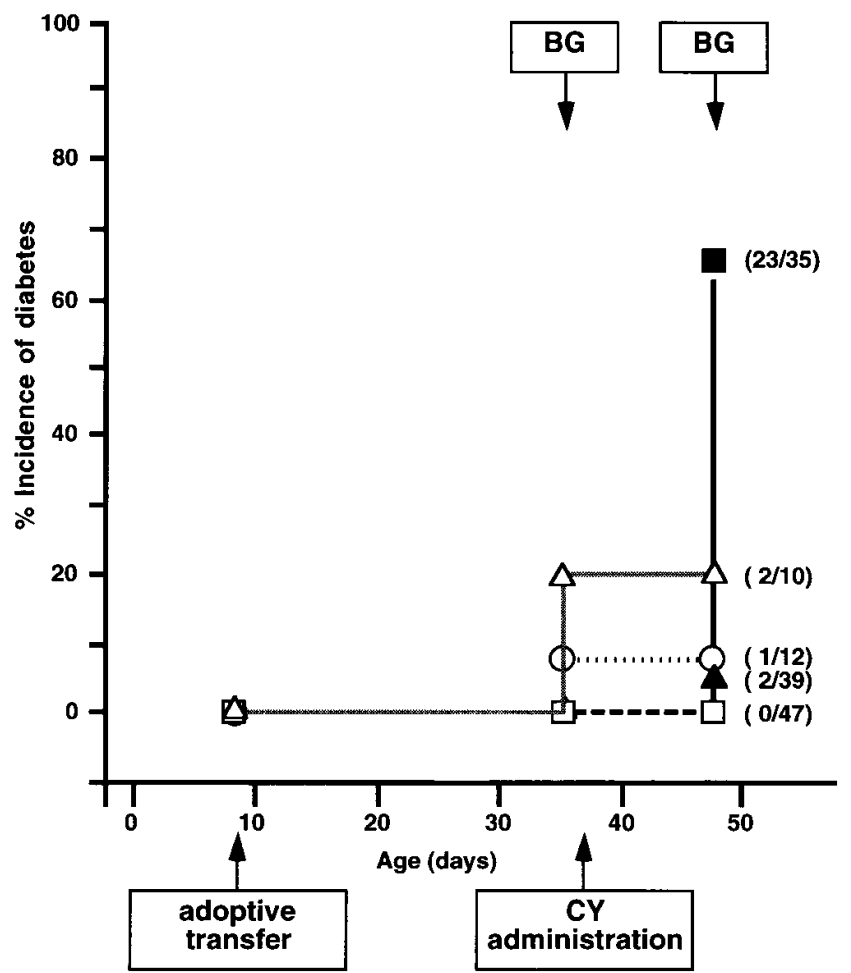

Figure 6. Time course of the incidence of diabetes. Percent incidence of diabetes in each group on the ordinate was plotted against the age of recipient NOD mice in days on the abscissa. Time course of the incidence of diabetes after the adoptive transfer of 2.0-6.0 $\times 10^{6}$ cells of wild type Th1 clones plus CY (closed squares) and minus CY (closed triangles), $\mathrm{PBS}$ administration minus $\mathrm{CY}$ or $\mathrm{CY}$ administration alone (open squares), IL-10-transduced Th1 cells plus CY (open circles), or the 1:1 mixture of 2.0-3.0 $\times 10^{6}$ cells each of wild type Th1 clones and IL-10-transduced Th1 cells plus CY (open triangles) is presented. Rectangles with arrows indicate the time of adoptive transfer at 8 , non-fasting BG measurement at 35 and 47, and CY administration at mixture of wild type Th1 clones and the corresponding IL10-transduced Th1 cells plus CY were graded for the severity of insulitis according to our criteria. As shown in Table II, the mean histological grade of insulitis in control NOD mice without adoptive transfer, CY administration alone, or adoptive transfer of wild type Th1 clones minus CY was $0.48,0.98$, or 1.85 , respectively, with the parallel shift in the percentage distribution of islets among four insulitis grades (Table II). Most islets of NOD mice after the adoptive transfer of wild type Th1 clones plus $\mathrm{CY}$ exhibited advanced insulitis of grade three (Fig. 7, $A$ and $B$ ) with the mean grade of 2.75, while acinar cells around islets were intact. In contrast, most islets of NOD mice after the adoptive transfer of IL-10-transduced Th1 cells plus CY exhibited periinsulitis or insulitis of grade one (Fig. 7, $C$ and $D$ ) with the mean grade of 1.43 , which was significantly lower than 2.75 after the adoptive transfer of wild type Th1 clones plus CY $(P<0.0001)$. The islets of recipient NOD mice after the adoptive transfer of the 1:1 mixture of both types of cells plus CY exhibited insulitis with the mean grade of 1.85 which was significantly lower than 2.75 after the adoptive transfer of wild type Th1 clones plus CY $(P<0.001)$, but without significant difference from that after the adoptive transfer of IL-10-transduced Th1 cells plus CY. The suppression of mean insulitis grade after the adoptive transfer of IL-10-transduced Th1 cells plus CY or the mixture of the two plus CY was associated with the parallel downward shift in the percentage distribution of islets among four insulitis grades.

\section{Discussion}

IL-10 in its large part is an immunosuppressive cytokine for macrophages and Th1 lymphocytes (27), which is in sharp con-

$37 \mathrm{~d}$ old. The incidence of diabetes started from 0 in all groups at age $8 \mathrm{~d}$ and reached the ratio of the number of diabetic mice/the total number of examined mice at age $47 \mathrm{~d}$ as shown in parentheses.

Table II. Distribution of Islets Among Four Insulitis Grades

\begin{tabular}{|c|c|c|c|c|c|c|c|c|c|}
\hline \multirow[b]{2}{*}{ Group No. } & \multirow[b]{2}{*}{ Treatment conditions } & \multirow{2}{*}{$\begin{array}{l}\text { Number } \\
\text { of mice }\end{array}$} & \multicolumn{4}{|c|}{$\begin{array}{l}\text { Percentage distribution } \\
\text { among insulitis grades }\end{array}$} & \multirow{2}{*}{$\begin{array}{l}\text { Mean grade } \\
\quad \pm S D\end{array}$} & \multirow{2}{*}{$\begin{array}{l}\text { Number } \\
\text { of islets }\end{array}$} & \multirow{2}{*}{$\begin{array}{c}P \text {-value } \\
\text { (Gr. No.*) }\end{array}$} \\
\hline & & & 0 & 1 & 2 & 3 & & & \\
\hline 1. & $\begin{array}{l}\text { Control } \\
(-\mathrm{CY})\end{array}$ & 6 & 53.5 & 44.9 & 1.6 & 0 & $\begin{array}{r}0.48 \\
\pm 0.17\end{array}$ & 168 & $\begin{array}{l}0.0001(5) \\
0.0005(6)\end{array}$ \\
\hline 2. & CY only & 6 & 15.8 & 70.8 & 13.4 & 0 & $\begin{array}{r}0.98 \\
\pm 0.16\end{array}$ & 152 & $\begin{array}{l}0.0005(1) \\
0.0001(4)\end{array}$ \\
\hline 3. & $\begin{array}{l}\mathrm{D}, \mathrm{G}, \mathrm{K}, \text { or } \mathrm{L} \\
\text { clone }(-\mathrm{CY})\end{array}$ & 6 & 0.6 & 47.7 & 27.8 & 23.9 & $\begin{array}{r}1.85 \\
\pm 0.29\end{array}$ & 192 & $\begin{array}{l}0.0001(1) \\
0.0005(2)\end{array}$ \\
\hline 4. & $\begin{array}{l}\mathrm{D}, \mathrm{G}, \mathrm{K}, \text { or } \mathrm{L} \\
\text { clone }(+\mathrm{CY})\end{array}$ & 6 & 0 & 1.7 & 21.6 & 76.7 & $\begin{array}{r}2.75 \\
\pm 0.12\end{array}$ & 122 & $\begin{array}{l}0.0001(3) \\
0.001 \quad(6)\end{array}$ \\
\hline 5. & $\begin{array}{l}\text { IL-10-transduced } \\
\text { D8 or G8 cells }(+\mathrm{CY})\end{array}$ & 6 & 2.4 & 62.7 & 24.4 & 10.5 & $\begin{array}{r}1.43 \\
\pm 0.24\end{array}$ & 192 & $\begin{array}{l}0.005 \text { (2) } \\
0.0001(4)\end{array}$ \\
\hline 6. & $\begin{array}{l}\mathrm{D} \text { or } \mathrm{G} \text { clone }+ \\
\mathrm{D} 8 \text { or } \mathrm{G} 8 \text { cells }(+\mathrm{CY})\end{array}$ & 6 & 0 & 46.9 & 30.4 & 22.7 & $\begin{array}{r}1.85 \\
\pm 0.50\end{array}$ & 137 & $\begin{array}{l}0.005 \quad(2) \\
=0.181(5)\end{array}$ \\
\hline
\end{tabular}

Group No. 1 and 2 denote age- and sex-matched NOD mice without adoptive transfer, and those with CY administration alone, respectively. Group No. 3 and 4 denote those after the adoptive transfer of wild type Th1 clones minus CY and plus CY, respectively. Group No. 5 denotes those after the adoptive transfer of IL-10-transduced Th1 cells plus CY, and Group No. 6 denotes those with the adoptive transfer of the 1:1 mixture of wild type D or G clones and corresponding IL-10-transduced Th1 cells of D8 or G8 clone, respectively, plus CY. P-value denotes the significance level in Student's unpaired $t$ test with data of the group No. indicated in parentheses. 
A

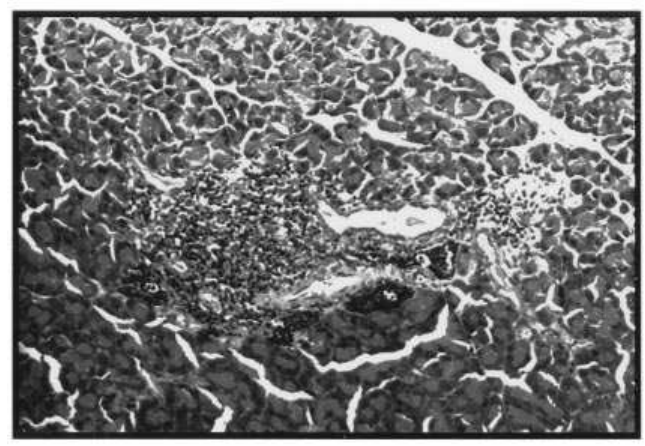

C

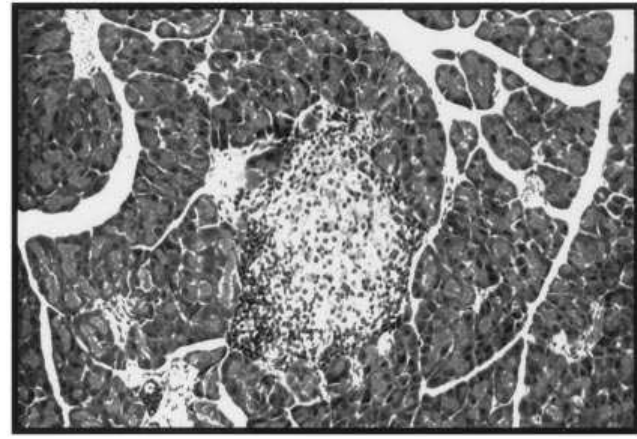

B

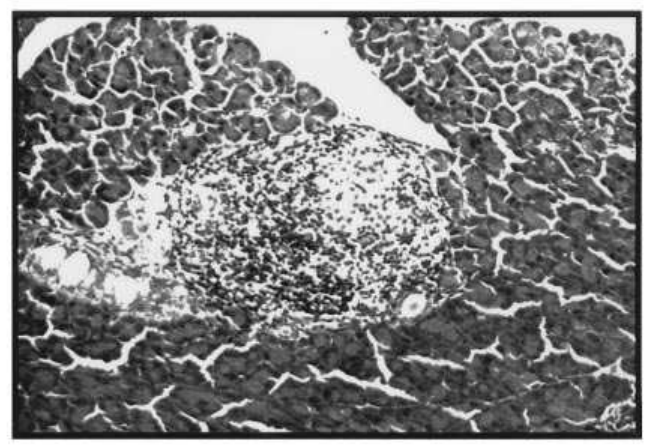

D

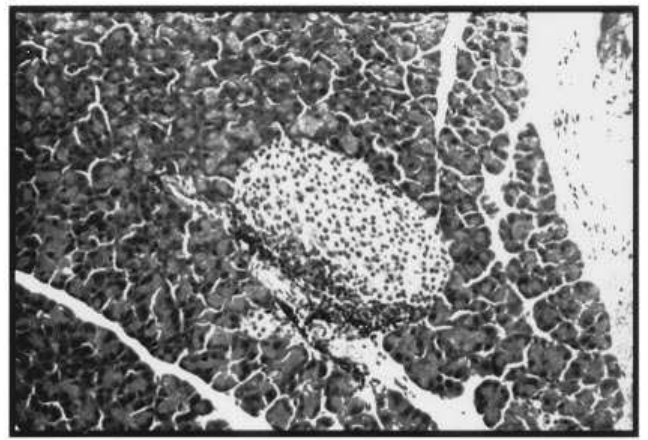

Figure 7. Histology. Representative hematoxylin and eosin-stained microscopic pictures $(\times 200)$ of recipient pancreatic islets at age $47 \mathrm{~d}$ are presented. ( $A$ and $B$ ) Severe insulitis of grade 3 after the adoptive transfer of wild type Th1 clones plus CY. (C and $D$ ) Periinsulitis or insulitis of grade 1 after the adoptive transfer of IL-10transduced Th1 cells plus CY. trast to its accelerating role for autoimmune diabetes in NOD mice under its transgenic expression in islet A- or B-cells (28, 29). The present study was conducted to examine the role of local IL-10, supplied through the adoptive transfer of IL10-transduced islet-specific Th1 clones (30) to neonatal NOD mice, for the initiation of immunological destruction of islet B-cells. These wild type islet-specific Th1 clones expressing IFN- $\gamma$ mRNA (Fig. $1 A$ ) were originally isolated from infiltrating lymphocytes in pancreatic islets of NOD mice. Their islet specificity was retained by stimulating them with islet cells of NOD mice as an Ag in vitro. The adoptive transfer of these wild type Th1 clones with different TCR repertoires (30) to NOD mice plus CY in our model triggered the advanced insulitis with the mean histological grade of 2.75 (Table II) and the comparable incidence of diabetes in each clone resulting in $66 \%$ (23/35) in total (Fig. 6). CY alone never induced diabetes in NOD mice $(0 / 22)$, but the mean histological insulitis grade of 0.98 after $\mathrm{CY}$ administration alone was higher than that of $0.48(P<0.0005)$ in control NOD mice. The adoptive transfer of wild type Th1 clones minus CY induced diabetes in 5\% (2/39) with the mean histological grade of 1.85 , which was even higher than that of 0.98 after CY administration $(P<0.0005)$.

The adoptive transfer of IL-10-transduced Th1 cells plus $\mathrm{CY}$ induced the low incidence of diabetes in $8 \%(1 / 12)$ and the mean histological grade of insulitis of 1.43 . In addition, the adoptive transfer of the 1:1 mixture of wild type Th1 clones and corresponding IL-10-transduced Th1 cells plus CY induced the low incidence of diabetes in 20\% (2/10) in total and the mean histological grade of insulitis of 1.85 compared to $66 \%$ and $2.75(P<0.001)$, respectively, after the adoptive transfer of wild type Th1 clones plus CY. The insertional mutagenesis of Th1 clones after retroviral IL-10-transduction was not regarded as the major factor for these suppressions for the following two reasons. First, because the similar suppression in the histological grade of insulitis and the incidence of diabetes was observed by the adoptive transfer of the heterogeneous IL-10-transduced Th1 cells without isolating IL-10-transduced Th1 clones. Second, because the similar suppression of both the histological grade of insulitis and the incidence of diabetes was observed in the mixture experiments using two different Th1 clones of D and G. The suppressed histological grade of insulitis in association with the suppressed incidence of diabetes after the adoptive transfer of not only IL-10-transduced Th1 cells plus CY, but also the 1:1 mixture plus CY strongly suggested that the expression of transduced IL-10 is responsible for their suppression. The slow induction of diabetes with CY in our study is regarded due to the following reasons. First, a single dose of CY of $200 \mathrm{mg} / \mathrm{kg} \mathrm{BW}$ used in our experiment was smaller than the total amount of 300 to $400 \mathrm{mg} / \mathrm{kg} \mathrm{BW}$ of CY in two divided doses separated by one or two weeks (35, 36), often used in other studies. Second, the earlier timing of $\mathrm{CY}$ administration at age $37 \mathrm{~d}$ in our study than those used in other studies, e.g., later than 10 wk old, explains the slow induction, because CY administered at the earlier time points is less effective in inducing diabetes in NOD mice $(35,36)$.

Because the neo gene was detected in the genomic DNA extracted from recipient islets after the adoptive transfer of IL10-transduced Th1 cells (Fig. 5 B), the adoptively transferred Th1 clones were shown to migrate and probably proliferate around pancreatic islets. The expression of IL-10 mRNA after the retroviral transduction of wild type Th1 clones was confirmed with RT-PCR (Figs. $1 B, 2 A$ ). The genomic contamination was excluded firstly because primers were designed in separate exons to cross an intron, and secondly because PCRproducts were not detected after omitting RTase from the reaction mixture (Fig. $2 \mathrm{~A}$ ). Because the retrovirus vector-medi- 
ated IL-10 mRNA was detected in isolated recipient islets after the adoptive transfer of IL-10-transduced Th1 cells plus CY (Fig. 2 B), the adoptively transferred IL-10-transduced Th1 cells were shown to produce IL-10 in situ. The level of total IL-10 mRNA assessed by the RT-PCR cycle-30 necessary to detect a band in recipient islets-was comparable, however, after the adoptive transfer of wild type Th1 clones or IL-10transduced Th1 cells (Fig. 3 B). We regard the unchanged total IL-10 mRNA in recipient islets to be mainly due to the assay limit of RT-PCR that is not sensitive enough to detect a small change in total IL-10 mRNA.

Although the IFN- $\gamma$ mRNA persisted in IL-10-transduced Th1 cells in vitro (Fig. $1 B$ ), its expression level was decreased, which was reflected by the larger RT-PCR cycle number of 35 necessary to detect IFN- $\gamma$ mRNA, compared to that of 30 in wild type Th1 clones (Fig. $3 A$ ). In recipient islets after the adoptive transfer of IL-10-transduced Th1 cells plus CY, IFN- $\gamma$ mRNA became visible only after 35 cycles of RT-PCR, while it was detected at as early as 30 cycles after the adoptive transfer of wild type Th1 clones plus CY (Fig. 3 B). Despite the limitation that the RT-PCR cycle number analysis gives the semiquantitative measure of mRNA levels only, the IFN- $\gamma$ mRNA level in vitro (Fig. $3 A$ ), and the level of IFN- $\gamma$ mRNA and its relative level to IL-10 mRNA in vivo (Fig. $3 \mathrm{~B}$ ) were both reproducibly decreased in the simultaneous assessment of IL-10 and IFN- $\gamma$ mRNAs as reflected by the larger RT-PCR cycle numbers.

We previously showed that IL-10 mRNA was detected after 35 cycles of RT-PCR in isolated pancreatic islets of NOD mice over $5 \mathrm{wk}$ old (28). In isolated pancreatic islets of NOD mice, IL-10 and IFN- $\gamma$ mRNAs were detected with the semiquantitative RT-PCR cycle number analysis after 40 and 35 cycles of PCR, respectively, both at age 5 and 8 wk (data not shown). These results proved that IL-10 and IFN- $\gamma$ mRNAs are produced in pancreatic islets in the natural course of islet B-cell destruction in NOD mice. IL-10 that is produced not only from adoptively transferred IL-10-transduced Th1 cells, but also from the cellular components of recipient pancreatic islets after their interaction with adoptively transferred wild or IL-10-transduced Th1 lymphocytes, is expected to exhibit their immunosuppressive function by decreasing IFN- $\gamma$ mRNA relative to IL-10 mRNA through autocrine and paracrine function of IL-10 without obviously changing the total IL-10 mRNA. IL-10 secreted from IL-10-transduced Th1 cells may have suppressed the immunological reactions not only in pancreatic islets, but also in secondary lymphoid organs which are the expected sites of action for the systemically administered IL-10. Although the detailed mechanism is the subject of our future study, the suppressed IFN- $\gamma$ production was assumed to suppress the initiation process of autoimmune diabetes through suppressing APCs to express MHC class II-associated antigens on their surface, leading to the suppression of diabetes incidence to $5 \%$.

The significant decrease in the mean histological grade of insulitis after the adoptive transfer of IL-10-transduced Th1 cells plus CY or the 1:1 mixture plus CY in our study (Table II) is compatible with the report by Katz et al. (37). Although Th1- or Th2-like cells with the identical TCR efficiently accumulated around pancreatic islets of NOD mice for the first few days after the adoptive transfer, they reported that only Th1like cells actively promoted diabetes resulting in insulitis of all islets, and that Th2-like cells, in contrast, did not progress be- yond the periinsulitis stage. Th2-like cells, however, did not provide protection against diabetes induced by Th1-like cells in their study. The protective role of IL-10-transduced Th1 cells in our study is also compatible with the report by Pennline et al. (18). They reported that the islets of NOD mice after the systemic administration of IL-10 were surrounded, but not infiltrated, by a small number of lymphocytes. Our histological results together with these studies support the notion that molecularly modified Th1 clones migrated to pancreatic islets to produce IL-10, and also suppress insulitis and the incidence of induced diabetes by wild type Th1 clones through adoptive transfer.

The difference in transgenic $(28,29)$ and lymphocytic expression of IL-10 with the resulting acceleration and prevention of diabetes, respectively, is assumed due to the difference in expressing or responding cells, timing, and IL-10 concentrations. Constitutive transgenic expression of IL-10 in islet A- or B-cells during the development of islet cells even before birth, induced prominent ductal proliferation, which was not reproduced by IL-10 expressed in Th1 lymphocytes to which islets were exposed from age 8 to $47 \mathrm{~d}$. The reversed effects of TNF- $\alpha$ to induce or prevent diabetes in NOD mice depending on the timing of its administration was reported by Yang et al. (38).

The local targeted delivery of IL-10 to islet-B cells through the adoptive transfer of IL-10-transduced islet-specific Th1 lymphocytes in this study proved for the first time that IL-10transduced Th1 cells could deliver IL-10 to recipient islets according to their TCR-specificity, and that they could suppress the insulitis and immunological destruction of islet B-cells in NOD mice through decreasing the relative level of IFN- $\gamma$ mRNA to IL-10 mRNA in recipient islets. Adoptive transfer of lymphocytes transduced with an immunosuppressive cytokine gene is in a mirrored analogy to a somatic gene therapy for melanomas using tumor-infiltrating lymphocytes transduced with a cytotoxic TNF- $\alpha$ gene (39). This animal model affords us the starting basis to develop the new concept of somatic gene therapy for autoimmune diabetes, in addition to the transplantation of proinsulin-producing fibroblasts $(40,41)$.

\section{Acknowledgments}

We sincerely thank K.W. Moore for providing us mIL-10 cDNA, rIL10, and hybridomas of SXC1 and SXC2, R.C. Mulligan for providing us $\psi \mathrm{CRE}$ and $\psi \mathrm{CRIP}, \mathrm{H}$. Land for providing us pBabe Neo, and S. Hamaguchi and T. Hashimoto for technical assistance.

This study was supported in part by a grant from Otsuka Pharmaceutical Factory Inc. for Otsuka Department of Clinical and Molecular Nutrition, School of Medicine, The University of Tokushima, Grant-in-Aid for Co-operative Research (A) 06304034, and Juvenile Diabetes Foundation Research grant 193141.

\section{References}

1. Castano, L., and G.S. Eisenbarth. 1990. Type-I diabetes: A chronic autoimmune disease of human, mouse, and rat. Annu. Rev. Immunol. 8:647-679.

2. Wicker, L.S., B.J. Miller, and Y. Mullen. 1986. Transfer of autoimmune diabetes mellitus with splenocytes from nonobese diabetic (NOD) mice. Diabetes. 35:855-860.

3. Serreze, D.V., E.H. Leiter, S.M. Worthen, and L.D. Shultz. 1988. NOD marrow stem cells adoptively transfer diabetes to resistant $(\mathrm{NOD} \times \mathrm{NON}) \mathrm{F}_{1}$ mice. Diabetes. 37:252-255.

4. Laface, D.M., and A.B. Peck. 1989. Reciprocal allogeneic bone marrow transplantation between NOD mice and diabetes-nonsusceptible mice associated with transfer and prevention of autoimmune diabetes. Diabetes. 38:894901.

5. Bendelac, A., C. Carnaud, C. Boitard, and J.F. Bach. 1987. Syngeneic 
transfer of autoimmune diabetes from diabetic NOD mice to healthy neonates: Requirement for both L3T4 ${ }^{+}$and Lyt-2 ${ }^{+}$T cells. J. Exp. Med. 166:823-832.

6. Miller, B.J., C.A. Michael, J.J. O'neil, and L.S. Wicker, 1988. Both the Lyt- $2^{+}$and L3T4 T cell subsets are required for the transfer of diabetes in nonobese diabetic mice. J. Immunol. 140:52-58.

7. Haskins, K., and M. McDuffie. 1990. Acceleration of diabetes in young NOD mice with a CD4 ${ }^{+}$islet-specific T cell clone. Science (Wash. DC). 249: 1433-1436.

8. Haskins, K., M. Portas, B. Bergman, K. Lafferty, and B. Bradley. 1989. Pancreatic islet-specific T-cell clones from nonobese diabetic mice. Proc. Natl. Acad. Sci. USA. 86:8000-8004.

9. Wong, F.S., I. Visintin, L. Wen, R.A. Flavell, and C.A. Janeway. 1996. $\mathrm{CD}^{+} \mathrm{T}$ cell clones from young nonobese diabetic (NOD) islets can transfer rapid onset diabetes in NOD mice in the absence of $\mathrm{CD}^{+}$cells. J. Exp. Med. 183:67-76.

10. McDaniel, M.L., J.H. Hughes, and B.A. Wolf. 1988. Descriptive and mechanistic considerations of interleukin 1 and insulin secretion. Diabetes. 37: 1311-1315.

11. Pukel, C., H. Baquerizo, and A. Rabinovitch. 1988. Destruction of rat islet cell monolayers by cytokines; synergistic interaction of interferon- $\gamma$, tumor necrosis factor, lymphotoxin, and interleukin 1. Diabetes. 37:133-136.

12. Mandrup-Poulsen, T., K. Bendtzen, J.H. Nielsen, G. Bendixen, and J. Nerup. 1985. Cytokines cause functional and structural damage to isolated islets of Langerhans. Allergy. 40:424-429.

13. Sarvetnick, N., D. Liggitt, S.L. Pitts, S.E. Hansen, and T.A. Stewart. 1988. Insulin-dependent diabetes mellitus induced in transgenic mice by ectopic expression of class II MHC and interferon-gamma. Cell. 52:773-782.

14. Stewart, T.A., B. Hultgren, X. Huang, S. Pitts-Meek, J. Hully, and N.J. Maclachlan. 1993. Induction of type I diabetes by interferon- $\alpha$ in transgenic mice. Science (Wash. DC). 260:1942-1946.

15. Serreze, D.W., K. Hamaguchi, and E.H. Leiter. 1989. Immunostimulation circumvents diabetes in NOD/Lt mice. J. Autoimmun. 2:759-776.

16. Zielasek, K., V. Burkart, P. Naylor, A. Goldstein, U. Kiesel, and H. Kolb. 1990. Interleukin-2-dependent control of disease development in spontaneously diabetic BB rats. J. Immunol. 69:209-214.

17. Rapoport, M.J., A. Jaramillo, D. Zipris, A.H. Lazarus, D.W. Serreze, E.H. Leiter, P. Cyopick, J.S. Danska, and T.L. Delovitch. 1993. IL-4 reverses T-cell proliferative unresponsiveness and prevents the onset of diabetes in NOD mice. J. Exp. Med. 178:87-99.

18. Pennline, K.J., E.R. Gaffney, and M. Monahan. 1994. Recombinant human IL-10 prevents the onset of diabetes in the nonobese diabetic mouse. Clin. Immunol. Immnopathol. 71:169-175.

19. Seino, H., K. Takahashi, J. Satoh, X.P. Zhu, M. Sagara, T. Masuda, T. Nobunaga, I. Funahashi, T. Kajikawa, and T. Toyota. 1993. Prevention of autoimmune diabetes with lymphotoxin in NOD mice. Diabetes. 42:398-404.

20. Jacob, C.O., S. Aiso, S.A. Michie, H.O. McDevitt, and H. Acha-Orbea. 1990. Prevention of diabetes in nonobese diabetic mice by tumor necrosis factor (TNF): Similarities between TNF- $\alpha$ and interleukin 1. Proc. Natl. Acad. Sci. USA. 87:968-972.

21. Deray-Sachs, M., C. Carnaud, C. Boitard, H. Cohen, I. Gresser, P. Bedossa, and J.F. Bach. 1991. Prevention of diabetes in NOD mice treated with antibody to murine IFN gamma. J. Autoimmun. 4:237-248.

22. Campbell, I.L., T.W. Kay, L. Oxbrow, and L.C. Harrison. 1991. Essential role for interferon-gamma and interleukin-6 in autoimmune insulin-dependent diabetes in NOD/Wehi mice. J. Clin. Invest. 87:739-742.

23. Mosmann, T.R., and R.L. Colfman. 1989. Th1 and Th2 cells: Different patterns of lymphokine secretion lead to different functional properties. Annu. Rev. Immunol. 7:145-173.
24. Fitch, F.W., M.D McKisic, D.W. Lancki, and T.F. Gajewski. 1993. Differential regulation of murine T lymphocyte subsets. Annu. Rev. Immunol. 11: $29-48$.

25. Powrie, F., and R.L. Coffman. 1993. Cytokine regulation of T-cell function: potential for therapeutic intervention. Immunol. Today 14:270-274.

26. Romagnani, T.R. 1992. Human Th1 and Th2 subsets: regulation of differentiation and role in protection and immunopathology. Int. Arch. Allergy. Immunol. 98:279-285.

27. Mosmann, T.R. 1994. Properties and functions of interleukin-10. $A d v$. Immunol. 56:1-26.

28. Moritani, M., K. Yoshimoto, F. Tashiro, C. Hashimoto, J. Miyazaki, S Ii, E. Kudo, H. Iwahana, Y. Hayashi, T. Sano, and M. Itakura. 1994. Transgenic expression of IL-10 in pancreatic islet A cells accelerates autoimmune insulitis and diabetes in non-obese diabetic mice. Int. Immunol. 6:1927-1936.

29. Wogensen, L., M.S. Lee, and N. Sarvetnick. 1994. Production of interleukin 10 by islet cells accelerates immune-mediated destruction of $\beta$ cells in nonobese diabetic mice. J. Exp. Med. 179:1379-1384.

30. Nakano, N., H. Kikutani, H. Nishimoto, and T. Kishimoto. 1991. T cell receptor $\mathrm{V}$ gene usage of islet $\beta$ cell-reactive $\mathrm{T}$ cells is not restricted in nonobese diabetic mice. J. Exp. Med. 173:1091-1097.

31. Morgenstern, J.P., and H. Land. 1990. Advanced mammalian gene transfer: high titer retroviral vectors with multiple drug selection markers and a complementary helper-free packaging cell line. Nucleic. Acids Res. 18:35873596.

32. Takebe, Y., M. Seiki., J. Fujisawa, P. Hoy, K. Yokota, K. Arai, M. Yoshida, and N. Arai. 1988. SR $\alpha$ promoter: an efficient and versatile mammalian cDNA expression system composed of the simian virus 40 early promoter and the R-U5 segment of human T-cell leukemia virus type 1 long terminal repeat. Mol. Cell. Biol. 8:466-472.

33. Danos, O., and R.C. Mulligan. 1988. Safe and efficient generation of recombinant retroviruses with amphotropic and ecotropic host ranges. Proc. Natl. Acad. Sci. USA. 85:6460-6464.

34. Lee, M.S., L. Wogensen, J. Shizuru, M.B.A. Oldstone, and N. Sarvetnick. 1994. Pancreatic islet production of murine interleukin-10 does not inhibit immune-mediated tissue destruction. J. Clin. Invest. 93:1332-1338.

35. Harada, M., and S. Makino. 1984. Promotion of spontaneous diabetes in non-obese diabetes-prone mice by cyclophosphamide. Diabetologia. 27:604606

36. Yasunami, R., and J.-F. Bach, 1988. Anti-suppressor effect of cyclophosphamide on the development of spontaneous diabetes in NOD mice. Eur. J. Immunol. 18:481-484.

37. Katz, J.D., C. Benoist, and D. Mathis. 1995. T helper cell subsets in insulin-dependent diabetes. Science (Wash. DC.). 268:1185-1188.

38. Yang, X.D., R. Tisch, and S.T. Singer. 1994. Effect of tumor necrosis factor $\alpha$ on insulin-dependent diabetes mellitus in NOD mice. I. The early development of autoimmunity and the diabetogenic process. J. Exp. Med. 180: 995-1004

39. Rosenberg, S.A., W.F. Anderson, M. Blaese, P. Hwu, J.R. Yannelli, J.C. Yang, S.L. Topalian, D.J. Schwartzentruber, J.S. Weber, S.E. Ettinghausen et al. 1993. The development of gene therapy for the treatment of cancer. Ann. Surg. 218:455-464

40. Selden, R.F., M.J. Skoskiewicz, K.B. Howie, P.S. Russell, and H.M. Goodmann. 1987. Implantation for genetically engineered fibroblasts into mice: Implication for gene therapy. Science (Wash. DC). 236:714-718.

41. Kawakami, Y., T. Yamaoka, R. Hirochika, K. Yamashita, M. Itakura, and H. Nakauchi. 1992. Somatic gene therapy for diabetes with an immunological safety system for complete removal of transplanted cells. Diabetes. 41:956961 